Research Report No. 49/2013

\title{
The Future of Legal Education: Three Visions and a Prediction
}

Harry W. Arthurs

Osgoode Hall Law School of York University, harthurs@osgoode.yorku.ca

Follow this and additional works at: http:// digitalcommons.osgoode.yorku.ca/clpe

\section{Recommended Citation}

Arthurs, Harry W., "The Future of Legal Education: Three Visions and a Prediction" (2013). Comparative Research in Law \& Political Economy. Research Paper No. 49/2013.

http://digitalcommons.osgoode.yorku.ca/clpe/291 


\section{OSGOODE}

OSGOODE HALL LAW SCHOOL

YOR K UNIVERSITY

\section{OSGOODE HALL LAW SCHOOL}

Comparative Research in Law \& Political Economy

RESEARCH PAPER SERIES

Research Paper No. 49/2013

The Future of Legal Education: Three Visions and a Prediction

Harry Arthurs

Editors:

Peer Zumbansen (Osgoode Hall Law School, Toronto, Director Comparative Research in Law and Political Economy)

John W. Cioffi (University of California at Riverside)

Comparative Research in Law \& Political Economy 


\title{
THE FUTURE OF LEGAL EDUCATION: THREE VISIONS AND A PREDICTION
}

\author{
H.W. Arthurs \\ York University, Toronto \\ Keynote Address \\ The Future of Law School Conference \\ Faculty of Law, University of Alberta \\ 27 September 2013
}

The theme of this conference is "the future of law school". That future depends on the future of many other things that are largely beyond anyone's control, especially the way in which developments in political economy, technology, demography and society affect the legal system, the market for professional services and the structure of higher education. But one crucial factor is very much within the control of law school: the values they embrace and they way they define their ambitions. How they do so will determine whether law schools collaborate with or resist, succumb to or transcend, the powerful forces that I have mentioned. It will determine whom they hire as faculty members and admit as students, what and how they teach, the standards they use to measure achievements and the way they allocate their scarce resources. And crucially, it will determine how — if at all — law schools exploit their strategic location as producers and distributors, as conservators and critics, of legal and social knowledge.

I'm going to present three quite different views of what law schools ought to be and ought to do. The first holds that their primary, if not their sole, function should be to produce "practice-ready lawyers" for today's profession. The second is that they should produce "tomorrow's lawyers", lawyers with the capacity to adapt to the rapidly and radically changing circumstances of legal practice. And the third is that law schools should play a leading role in the creation and transformation of legal knowledge, legal practice, and the legal system - a role that requires them to provide their students with a large and liberal understanding of law that will prepare them for a 
variety of legal and non-legal careers. I'll end by making a prediction about which model represents the future of law school. Or perhaps you've guessed already.

\section{Training today's lawyers}

I'll begin with the widely-held view that it's the job of law schools to produce practiceready lawyers. This view is particularly important in light of recent action by Canada's law societies to require law schools to ensure that their students possess knowledge of certain fields and acquire certain "competencies" to ensure they're ready to practice. Unfortunately, producing practice-ready lawyers is something law schools can't do. The problem is that no one knows what practice-ready lawyers look like. We lack information about what legal practitioners do, what knowledge or competencies they actually need or use, what breadth and depth of knowledge qualify new graduates as "ready" to practice, or how long they will remain "ready" before what they learned at law school becomes obsolete. These are empirical questions. However, they were neither asked nor answered before the law societies adopted their new regulations.

That said, we are virtually certain of one fact about the profession: it is fractured along a number of deep fault lines. Those lines run vertically and divide general practitioners from specialists, specialists from each other, and both from the remaining one-third of law graduates who are employed outside the private practice of law, in government agencies, clinics or corporate law departments or in non-legal capacities in business, the media or politics. No less importantly, in private practice the fault lines run horizontally as well as vertically: the profession is stratified. As one descends from higher to lower strata, the clientele tends to becomes less affluent, the work less complex and more routine, and the rewards more meagre. For these reasons, as one traverses the grid formed by these intersecting vertical and horizontal fault lines it is almost certain that the scope and depth of what lawyers need to know changes as well. 
If I'm right, if what lawyers need to know in order to be practice-ready varies considerably from one kind of practice to another, we arrive at an important conclusion: one size of legal education will not fit all law graduates. But quite inexplicably, Canada's law societies believe that it will. They have recently decreed that all law schools must ensure that all students acquire all "competencies" and knowledge of all the substantive subjects or fields specified in their new regulations. For that matter, law societies assume that not only all new graduates but all established practitioners know the same things. That's why they allow them to undertake all kinds of work that clients may entrust to them -murder trials or IPOs, divorces or patent applications. That's why they don't re-test lawyers to ensure they've kept their law school learning up-to-date; why they don't give them qualified licenses that allow them to practice in some fields and not others; and why they don't - except in rare circumstances discipline lawyers for incompetence or ignorance. To reiterate, the official position seems to be that since all lawyers are presumed to be omni-competent, they must all be trained in the same way so as to ensure that they possess a common core of knowledge for at least one brief moment in their careers. This position totally ignores the effects of specialization and stratification - two forces that most powerfully determine what lawyers need to know in order to practice competently. If this position prevails, if the recent law society regulations remain in force, whatever else law schools do, they will never be able to produce practice-ready lawyers.

\section{Training tomorrow's lawyers}

And law societies have ignored something else too: the relentless change that is destabilizing existing legal institutions, rules, processes and patterns of practice. By contrast, the Canadian Bar Association in its recent Legal Futures discussion paper identifies the drivers of legal change: technology, politics, economics and demography. We know that family structures, business practices, regulatory technology, forms of property, patterns of social deviance, strategies of social control: all of these are in flux. Consequently, statutes are amended, common law rules mutate, and legal routines and boilerplate change more frequently and drastically than they used to. The 
implications for legal education are important. As the CBA's discussion paper notes, "with the speed of change taking place in the legal environment, choices made at the beginning of a student's course of study may be outdated by the time he or she completes all of the necessary requirements for practice" - requirements, I might remind you, that were set in stone by Canada's law societies. I'll walk you through a few obvious examples.

Over three or four decades, globalization has transformed the production of goods and services, corporate structures, the international division of labour, the dissemination of intellectual property and finance capital and - as a consequence - the norms, modalities and location of many regimes of corporate governance and regulation. In doing so, globalization has also dramatically altered the market for legal services, the structure of the law and consulting firms that deliver those services, the knowledge base of lawyers who advise global businesses, the content of law school curricula and the focus of legal scholarship.

Technology next. Technology has not only enabled globalization. It has had a direct effect on legal practice. Some examples: By facilitating the digitization, outsourcing or offshoring of routine "back-of-house" functions, technology has allowed large law firms to reduce their complement of articling students and junior associates which, in turn, has destabilized their business model. By disseminating legal information online, technology has allowed retail purchasers of standard legal services to access self-help sites and permitted online service providers to undercut the lower-tier law firms that formerly depended on such services for their core business. And by enabling electronic searches, technology has not only made legal research faster and cheaper; it has blurred the boundaries amongst legal categories and between law and adjacent disciplines. In effect, technology has expanded law's territorial reach and intellectual horizons while shrinking its market share.

Now a brief word about demography. Like the rest of the Canadian workforce, the legal profession is not only aging. It is attracting more and more women and growing more 
and more ethnically diverse. These developments have had important implications for the deployment, financial fortunes, governance and education of lawyers. Some illustrations: diversity has forced large law firms to embrace meritocracy as a recruitment policy, undermined the image of law as a "gentleman's profession", and generated pressures for greater democracy in the profession's governing bodies. Meritocracy has also -ironically - converted law schools into gatekeepers, whose badges of "merit" largely decide which graduates will, and which will not, gain access to the most coveted opportunities the profession has to offer. But meritocracy has not completely won the day. Discrimination and prejudice persist. Many highly qualified women feel obliged to leave elite firms for jobs in government and corporate law departments where they find the work environment more supportive. And students from immigrant and racialized minority groups - who often confront economic, linguistic and social barriers before, during and after law school - tend to cluster in disproportionate numbers in lower-tier solo practices or small firms. These new patterns of recruitment and practice have undermined the bar's traditional reliance on informal socialization as a strategy for instilling professional values in its members. Perhaps this explains why law societies have recently decreed that law schools must instruct their students in "professionalism"- a project that the profession itself is no longer willing or able to undertake, underwrite or even define.

I have tried to show how political economy, technology and demography have become drivers of change not only in legal rules and institutions, but in legal practice and ultimately legal education. However, to reiterate, the profession's governing bodies have ignored the challenge of educating lawyers for an uncertain future just as resolutely as they have ignored the need for hard evidence about how lawyers actually practice in a multi-dimensional present. One thing is certain: making graduating students tick all the boxes on an arbitrary list of "competencies" and fields of substantive law is no way to ensure that they will be "practice ready" today, much less that they will stay that way for the rest of their careers. 
The CBA's discussion paper — which is very future-oriented — somewhat tentatively suggests that "[l]aw faculties should continue to play an important role in teaching the theory of law, legal principles and legal reasoning." It then adds: "While some observers would have them place increased emphasis on the practice of law, law schools in their current form may not be the best option for providing practice training." This suggestion that law schools should focus on "theory..., principles... and reasoning", this scepticism about their role in "practice training", is in part intended to ensure that law graduates have the intellectual tools they need to adapt to the changing but unpredictable requirements of legal and other careers. But in part it represents a strong hint that law schools should focus on what they do best.

\section{Transforming legal knowledge, legal practice and the legal system.}

What do they do best? Law schools are knowledge communities: they exist to collect, critique, produce and disseminate knowledge. We therefore need briefly to consider what we mean by knowledge in the context of law. Obviously the profession is (or should be) as concerned about knowledge as the academy. After all, its monopoly over legal practice rests on the claim that lawyers know things that other people don't. However, the profession and the academy relate to "knowledge" differently.

Practitioners tend to consume knowledge, academics to produce it. Practitioners tend to know what they need to know, academics to know what they want to know. Practitioners tend to treat knowledge as a given; academics to treat it as contingent, as being constantly revised by new evidence, new methodologies, new theories, new ways of knowing. Practitioners and academics both need to master non-legal domains of knowledge, but many practitioners are reluctant to admit this, while most academics celebrate inter-disciplinarity. And finally, practitioners especially value tacit knowledge, practical knowledge that is gained through experience, disseminated through mentorship and deployed in response to trained reflex; academics prize explicit knowledge, knowledge that can be systematized, taught, published, and falsified. 
It's easy to see, then, that disagreements between the academy and the profession about the nature of knowledge are at the root of disagreements over who should control law schools - the profession's governing bodies or the universities and their law faculties. The future of law schools, I argue - and the future of law as a profession, social institution and intellectual discipline - depends on who controls knowledge. Law schools cannot function well as knowledge communities if their view of knowledge is disparaged, marginalized or suppressed because it conflicts with that of the profession; if legal orthodoxy has a privileged place on the curriculum and a preemptive claim on resources; if critical scholarship and transformative pedagogy are seen as illicit attempts to subvert professionalism; if research, graduate studies and public advocacy come to be seen as derogating from the "true" or "core" mission of law schools or as mere decorative appendages to it.

To return to the main thrust of my argument: if the academy must be free to collect, critique, produce and disseminate knowledge as it thinks best, how should it use that freedom? In two ways: First, in a world that's in flux, in a legal universe that is increasingly chaotic, it's the academy's job to make sense of it all. The academy should therefore chronicle change, identify continuities and discontinuities, demonstrate causes and effects and explain whose interests and which values are being advanced or attacked. The academy should advocate for change intelligently when it deserves support and fiercely resist it when it doesn't. And the academy should wrestle with change: it should propose new statutes, conjure up new doctrines and invent new instruments of private governance. And now my second response. In its engagement with change, the academy must not only think about, write about and wrestle with change. It must equip future legal architects and legal artisans with the tools to enable them cope with change. And finally, as the CBA discussion paper makes clear, change requires that legal scholars and students, legal practitioners and policy makers, venture into new domains of theoretical and practical knowledge. Academics in adjacent disciplines, experts in government agencies and private consultancies, leaders in business and social movements all have a great deal to tell us. To engage these "relevant others" in meaningful conversations, we must learn talk to 
them in their own vernacular. This is perhaps our greatest challenge: to learn to integrate law-talk with other discourses.

Putting change at the centre of what they do will be hard for law schools - especially with regard to their lawyer-training functions. However, they have already made a good start.

First, law schools have generally abandoned the notion that legal education is only about teaching legal rules. Instead law schools generally aim to train students to "think like lawyers" - to develop generic analytical and critical skills that can be deployed over time and across a wide variety of legal and non-legal contexts. This is certainly better than insisting - as law societies perversely do - that all lawyers must know the same things. But the current strategy is still somewhat problematic. Perhaps, like pornography, we can recognize "law-think" when we see it. However, there is little empirical evidence that all lawyers think alike, that they analyse legal problems in similar fashion, that "law-think" occupies a significant part of their working days, or that lawyers think differently from, say, social workers, literary critics or corporate executives. Indeed within legal-academic circles, there is a robust debate about what it means to "think like a lawyer". One distinguished legal scholar has recently argued that "[t]hinking like a lawyer is thinking like a human being, a human being who is tolerant, sophisticated, pragmatic, and engaged." On the other hand, there's an extensive literature that argues to the contrary, that "thinking like a lawyer" involves a distinctive repertoire of analytical and discursive strategies. But whichever position one favours, it's important to remember that lawyers who can't, won't or don't also think like human beings are quite likely to harm themselves, their clients, the reputation of the bar and the effectiveness of the legal system.

This leads me to a second strategy — inter-disciplinarity — which (as I've suggested) law schools have been preaching for decades, and sometimes actually practice. Interdisciplinarity takes many forms: joint degree programs, the cross-appointment of scholars from other disciplines to teach law school courses, so-called "law and..." or 
"perspective" courses and, most commonly, casebook and classroom references to economic, political, sociological, philosophical and historical perspectives on legal issues. Interdisciplinary teaching is difficult: many law professors aren't well-trained or well-read in other disciplines; appropriate materials are sometimes hard to come by; students are often resistant. However, most legal academics - like the CBA - are convinced that inter-disciplinarity is an essential element of the response to change: it shakes lawyers loose from the notion that law is unchanging and unchangeable; it gets them into the habit of thinking outside the legal box; and it helps them better understand just what's in that box. Inter-disciplinarity, depending on your point of view, is either a complement or a corrective to thinking like a lawyer.

A third, related strategy long ago adopted by law schools, but still resisted by the profession, is the optional curriculum. Optionalization is meant to engage students intellectually and, at the same time, to help them to prepare for varied and unpredictable futures. There's not much downside to the optional curriculum. If law schools are primarily teaching students how to think, one subject will serve as well as another. To the contrary: the optional curriculum has distinct advantages. Students with different interests and career aspirations will sensibly want to study subjects that seem relevant to those aspirations. Consequently, optionalization enhances motivation. And there's yet another advantage: if graduates are going to have to educate themselves during their future careers, in order to adapt to a changing society, economy and legal system, they must learn to learn. The optional curriculum - if it is properly structured and involves advanced, interdisciplinary and capstone courses, as well as research and writing requirements - ensures that students will do just that. In particular, it allows them to develop integrative skills, to locate what they've learned in a larger and more flexible frame that can absorb new material as it comes their way over the years. And one more point: the optional curriculum gives scholar-teachers an opportunity to use their classroom or seminar room as a testing ground for new ideas and as a conduit for disseminating those ideas to future generations of practitioners and policy makers. Consequently, it is an important vehicle for the renewal of the legal profession and the justice system. 
Finally, law schools are increasingly committed to experiential learning. They believe that immersing students in real or simulated legal situations has several advantages. Like the optional curriculum, experiential learning enhances motivation. It exposes students to certain intractable facts of legal life - the legal power of deep pockets, for example, or the stultifying effects of déformation professionelle - that are difficult to convey through conventional course materials. And it incites them to think critically and systemically as well as analytically. But l'll add a note of caution: there's a risk that experiential learning can degenerate into mere skills training. Obviously, if students do learn something about negotiation or counselling or advocacy, that's a good thing. However, experiential learning is not simply to show students how to put "lawthink" to practical use; it is to enable them to confront the normative, logistical and relational issues that are imminent in all legal encounters. In this sense, the success of experiential learning depends ultimately on the strength of law schools as knowledge communities, on their ability to provide students with context and perspective that allow them to make sense of what they've observed or experienced.

The future of law schools, then, is to embrace their vocation as knowledge communities, and to embed their JD and other educational programs within their larger mandate of aggregating, critiquing and disseminating knowledge, in the context of rapid and profound changes in society and in law. I have identified four strategies that law schools have developed to advance this view of legal education, strategies that are consistent with the CBA's admonition that they should focus on "theory..., principles... and reasoning" and not on skills training. To summarize: law schools should be teaching students to think like lawyers, to contextualize and critically evaluate their legal experiences, to adapt to change and, especially, to learn how to learn. If law schools don't do these things, no one will, and their graduates will be worse lawyers, worse citizens and worse people as a result.

Now I have to address a tough question: if that's all that law schools do, is it enough? If their graduates don't have legal skills and don't know substantive law, aren't they 
likely to be a risk to their clients, their colleagues and their liability insurers? I think not. There's good reason to believe that new graduates with limited knowledge of substantive law and a limited repertoire of skills can still end up as highly successful practitioners. Let me remind you that many famous jurists had very rudimentary legal educations; that many specialists today never took courses in the fields in which they excel; and that most skilled advocates, draftspersons and negotiators learned their trade on the job, not at law school. In the United States, graduates of law school that prize scholarship, schools with wide-open curricula that emphasize thinking skills, theory and inter-disciplinarity - fare well even in today's difficult legal labour market. They are far more likely to be hired (and for better jobs) than graduates of the other sort of schools, those whose faculty don't publish and whose curricula emphasize "basics" and "preparation for practice". And the large consulting firms that compete successfully with law firms in many key markets tend to hire people with on the basis of their intellectual abilities, not professional "competencies". Nor is any of this surprising: in most labour markets today, sophisticated and adaptable knowledge-workers tend to fare better than semi-skilled workers with a limited repertoire of skills and know-how closely aligned to the current modus operandi of particular employers or trades.

Let me carry that last thought forward. If my original description of the legal profession as divided by deep fault lines is anywhere near accurate, the bar may one day recognize not just one class of members, but many. Members of each class would have different educational credentials, and a limited license to practice - just as Ontario paralegals and solicitors do today. I can imagine, for example, that general practitioners will one day be licensed (say) to appear as advocates in certain tribunals and the lower courts, and to do routine real estate transactions, simple incorporations and uncontested divorces - but not to undertake (say) appellate litigation, patent applications or tax planning. The classes of membership would likely not be water-tight. There would likely be competition, for example, between paralegals and general practitioners in the provision of routine services; and members of each class should have the chance to move up the ladder. If such a system of licensing were adopted, the future of law schools would look quite different from the one l've proposed. They 
might offer a skills-based one-year degree for paralegals, a stripped-down two-year "basic" degree for general practitioners, an enhanced four year degree for specialist practitioners, and conversion courses for those who want to upgrade their credentials.

This model has certain attractions: it saves time and money for those who will end up in general practice; it ensures that higher level lawyers possess the theoretical, analytical and contextual sophistication required to deal with complex and multi-dimensional issues; and it enables law schools and other education providers to customize their curricula to fit the diverse needs of their students. These are clear advantages, but there are risks as well. A clear division between faculty members who teach "basics" to paralegals and general practitioners, and those who teach future legal specialists, intellectuals and policy advisors is likely to engender squabbles over the soul of law schools, or at least over their budgets. And there are risks for students too: stripping the generalist program down to basics might foreshorten the horizons and stunt the ambitions of the students enrolled in it.

But don't worry about the risks. It's not going to happen. Law schools won't be redesigned to support a system of multiple professional credentials, because the profession will never adopt such a system. For the foreseeable future, there will be only one proper professional credential - barrister and solicitor, and only one main route to obtaining that credential - via an "approved" JD degree, one that ticks all the boxes specified in the new law society regulations. However, it will be difficult to tick those boxes if law schools remain true to their character as knowledge communities, if they persevere with scholarship, law reform, public advocacy and graduate studies, and if they insist on giving JD students a liberal education in law. Law schools will somehow have to square this circle. They will either have to challenge the new regulations directly, or feign compliance and hope that no one notices. If they don't there will be more and more boxes to tick and less and less opportunity to do all the other things law schools should be doing. 


\section{Conclusion}

The future of law schools is uncertain: all the social, political and intellectual forces that shape legal education are in flux. Their future is contested: the academy and the profession are fundamentally at odds over the nature of knowledge, the best way to educate lawyers and many other matters. And their future is plural: different law schools will have different futures. Nonetheless, I will venture a prediction. When this law school celebrates its bi-centenary in 2113 , when speakers look back on its second century of accomplishment, they will mention distinguished scholarship more often than skills training, they will mention its long-term contributions to the public good more often than its immediate influence on present-day legal practice, and they will mention its role as an agent of change more often than its role as a faithful purveyor of conventional wisdom.

Taking the long view and focussing on change will, I know, seem like typical academic self-indulgence to those of you whose job it is to ensure that the public receives high quality professional services in the here and now. Describing law schools as multifunctional knowledge communities rather than institutions single-mindedly devoted to the training of practice-ready lawyers will seem like a callous indifference to the plight of students and recent graduates who face mounting debts and declining job opportunities. And my apparent downgrading of "hard law" and "how to" courses and my privileging of theory and thinking, of inter-disciplinarity and contextualization, will appal many of my academic colleagues. To all of the above I apologize if (as they say) I've inadvertently given offence. But I'm willing to bet that when the time capsule is opened 100 years hence, when someone removes the crumbling copy of my remarks and matches them against the historical record, I'll turn out to have been right. And not only right but helpful to those charged with upholding professional standards, prescient in my advice as to what kind of education will help students survive and flourish in volatile legal labour markets, and so modest in my prescriptions for reforming the law curriculum as to seem hopelessly conservative to my academic heirs and assigns. 